\title{
The effects of migration on poverty and inequality in rural Kosovo
}

\author{
Judith Möllers ${ }^{*}$ and Wiebke Meyer
}

\author{
* Correspondence: moellers@iamo.de \\ Leibniz Institute for Agricultural \\ Development in Transition \\ Economies (IAMO), \\ Theodor-Lieser-Str. 2, 06120 Halle, \\ Saale, Germany
}

\begin{abstract}
The economic wellbeing of a large number of rural Kosovar families depends heavily on migrants' remittances. This paper aims at analysing the impact of migration on rural poverty and inequality in Kosovo. It draws on the 2009 nationally representative Kosovo Remittance Study. Analyses are based on a comparison with counterfactual migrant household incomes derived from Propensity Score Matching. We find that remittances have no impact on the extremely poor, but lift around $40 \%$ of migrant households above the vulnerability threshold. Gini coefficients show a tendency to increase due to migration. Determinants of different outcomes of migration are explored in a logit regression on migration success. Household and income structure as well as education play a role in how migrant households climb up the income ladder.

JEL: F22, F24, O15, P36

Keywords: Migration; Remittances; Poverty; Inequality; Kosovo; Propensity score matching
\end{abstract}

\section{Introduction}

Migrant remittances are known to be an important and stable source of income, not only in the developing world, but also in many transition economies. Indeed, European transition countries such as Albania, Moldova, and Bosnia and Herzegovina are among the top recipients of remittances as a portion of gross domestic product (GDP) (Mansoor and Quillin 2006).

In Kosovo, around one fifth of households are involved in labour migration, with this proportion slightly higher in rural areas (United Nations Development Programme 2010). Migration is well-known to be a coping strategy and a source of income that compensates for the low employment rates in the country (Corbanese and Rosas 2007). The very high unemployment rate of around 40\%, plus the estimated number of 200,000 young people who will enter the labour market within the coming five years, increases the pressure to migrate. Indeed, $50 \%$ of the younger generation say they would emigrate if they could (Haxhikadrija 2009). Currently, between 315,000 and 500,000 Kosovars live abroad, of whom about 50\% reside in Germany. It is estimated that every third household in Kosovo has family members living abroad (Mustafa et al. 2007; European Stability Initiative 2006).

There is hardly any official and reliable data available on the remitted sums resulting from this migration, because considerable amounts of the money are transferred informally (World Bank 2010). The United Nations Development Programme (2010) estimates the absolute amount of remittances in 2009 as $€ 443$ million. The share of remittances is estimated to represent around 13\% of GDP. 
Despite its economic importance for the country, relatively little is known about migration and remittances in Kosovo, which have been widely underrepresented in the migration and development literature (Vathi and Black 2007). Although a number of studies have been published recently, most of the analyses are descriptive. The recent report of Gashi and Haxhikadrija (2012) nicely summarises results of available data and migration literature on Kosovo. Havolli (2011) and Meyer et al. (2012) provide more detailed analyses of the drivers of remitting. When the impact of remittances on households in Kosovo is analysed, this is done based on a simple comparison of recipients and non-recipients: for instance, in Haxhikadrija (2009); Möllers et al. (2013); and Elezaj et al. (2012).

In this contribution we highlight the impact of remittances on the welfare and income distribution of the rural population ${ }^{1}$. The paper adds to the debate on the linkages between remittances and poverty and inequality (see, for instance, Taylor 1992; Adams 2011; Lokshin et al. 2010). Unlike earlier studies on Kosovo, we base our analysis on counterfactual incomes derived from Propensity Score Matching (PSM). Our main aim is to quantify the income-related outcomes of migration on (migrant sending) rural households. In addition to changes in poverty and inequality indicators, we also explore factors that determine household based success of migration (measured as an upward shift in income quintiles among migrant households).

The paper is structured as follows: after a brief survey of the literature in Section 2, we introduce our methodology and data in Section 3. Section 4 provides a descriptive comparison of migrant and non-migrant households. The main analytical results are presented in Section 5. We start from a comparison of income groups. Based on headcount indices and using counterfactual incomes, we then determine the share of migrant households that would fall into poverty without remittances. We show if and how the rural income distribution is affected by mixed income structures - and especially by remittances. To analyse the marginal effect of remittances on inter-household income distribution we calculate decomposed Gini coefficients and Gini elasticities. Finally, an econometric analysis of the success factors linked to whether a rural migrant household will climb up the income ladder is presented. The procedure applied for this is a logit regression. Section 6 concludes.

\section{A brief survey of the literature}

This section briefly introduces migration and poverty related facts about Kosovo and presents some key results and arguments of the discussion on the effect of migration on poverty and inequality.

Kosovo's economic situation is, and for a long time has been, challenging. The country was historically one of the poorest in the region, and it is still struggling with high levels of poverty and low growth rates which, despite progress in recent years, are still too low to significantly affect poverty reduction and extreme unemployment (United States Agency for International Development 2008). The per capita income was estimated at only $€ 1,760$ in in 2009 (Gashi and Haxhikadrija 2012). This is also reflected in the high shares of $34 \%$ and $12 \%$ of the population falling below the absolute and extreme poverty lines respectively in 2009 (World Bank and SOK 2011); the Gini index is, however, relatively modest at 0.30 (World Bank 2007a). The role that migration and remittances might play in Kosovar households is reflected in the fact that nearly one in ten households in Kosovo indicate that remittances are their main income source 
(Statistical Office of Kosovo 2010). The share of the population which receives remittances (around 20\%) is substantially higher than the fraction receiving social assistance (about 13\%); the average amount of remittances is three times higher than the average values from social protection programmes in recipient households. There is also evidence that rural areas in particular, where poverty is usually more pressing than in urban areas, enjoy higher average amounts of remittances (United Nations Development Programme 2010; World Bank 2007a).

The World Bank (2007b) highlights migration as one of three (complementary) pathways out of rural poverty (the other two being farm intensification and specialisation, and entering local non-farm labour). Indeed, the potential of migration and remittances to significantly reduce acute poverty is widely discussed in the literature (Adams and Page 2005; Lokshin et al. 2010). A large, and growing, number of multidisciplinary micro-studies show that (temporary) migration helps to smooth seasonal income fluctuations, to provide extra cash to meet contingencies, or to increase disposable income (e.g. Mosse et al. 2002; Adams et al. 2008; Lokshin et al. 2010; Verme 2011; for an overview of empirical studies in developing countries see Adams 2011).

While there is not much doubt that remittances increase the incomes of recipient households, their use is also important when discussing impacts on development. There is much evidence that remittances are used primarily to increase consumption, in particular of food and clothing, and less frequently for investment purposes (Davis et al. 2010; Mansoor and Quillin 2006) $)^{2}$. Haxhikadrija (2009) reports that in Kosovo the receipt of remittances is often followed by the purchase of leisure goods such as satellite dishes, mobile phones or cameras. Next to daily expenses, rural households primarily use remittances to improve their basic equipment, whereas investment in education seems rather rare; in rural areas the differences in the possession of goods, such as televisions, refrigerators, washing machines and cars, between migrant and non-migrant households are clearly visible. As such expenses frequently flow into imported goods, trickle down effects and thus longer term impacts on development and poverty reduction may be hampered. For farm households in neighbouring Albania, Miluka et al. (2010) suggest that migration is used by rural households as a way out of agriculture. For Kosovo there are, however, no indications that significant amounts of remittances are used for this purpose, yet, those few households that do report business investments often make use of remittances (Möllers et al. 2013; Gashi and Haxhikadrija 2012).

Another much debated issue is about who actually migrates and who receives remittances. The causal link between migration and the wealth status of the labour-sending household has direct implications for poverty and inequality effects. If people are in a position to migrate (and increase their income) because they are better off in the first place, then poverty effects will be lower. Most studies find that richer households receive more remittances (Mansoor and Quillin 2006). However, a clear causal link cannot be made, because the drivers and impacts of migration are complex. Remittance flows depend on different underlying motives for getting involved in migration and for remitting. In the home country household not only the financial flows but also the decision to send migrants induces adjustments in the labour endowment and thus in income (and probably also consumption) strategies (e.g. Meyer et al. 2012; Davis et al. 2010).

Similarly, inequality effects depend on the share of households receiving transfers, the average amounts received (or how much migrants remit), and the distribution of remittances among the population (which households are sending migrants and 
receiving remittances) (Giannetti et al. 2009). If the economic position of the remittee household is improved through remittances then overall inequality in the communities might rise as a consequence (de Haan and Rogaly 2002). Whether or not migration increases income inequality of the sending households due to the receipt of remittances has not yet been fully clarified. Some researchers expect an increased inequality, for instance if information and education are decisive for the (self-)selection of migrants (Milanovic 1987). Indeed, Adams (2011), who reviews a large number of empirical studies, finds that at the country level international remittances tend to increase income inequality. Others argue that remittances contribute to a more equal income distribution, especially if trickle down effects are at work. Taylor and Wyatt (1996), for instance, find that the indirect effects of remittances affect the household farm income distribution positively. Giannetti et al. (2009) present small but equalising distributional effects for a number of Eastern European countries. Barham and Boucher (1998) argue that inequality outcomes are sensitive to the choice of method. Differences can, for example, be attributed to value judgements regarding the weight attached to certain income groups when constructing inequality measures (Stark et al. 1988).

In summary, the literature does not provide clear directions for the effects of migration on home country households. We base our analysis of Kosovo on the widely accepted hypothesis that migration has positive direct effects on both migrants' rural incomes and rural incomes in general. Thus, we expect remittances to reduce poverty, even if a counterfactual income is used for comparison. We further expect remittances to increase inequality, as migrants tend to be concentrated in better educated and wealthier households.

\section{Methodology and data}

This paper draws on the recent and representative dataset of the Kosovo Remittance Study (KRS) (United Nations Development Programme 2010). The KRS acknowledges the major importance that remittances play in the economy of Kosovo. Its particular strength is its large sample of 4,000 households which allows for a truly quantitative view on the issue. Our study looks at a subsample of 1,727 rural households from this database $^{3}$. The sample size is reduced due to missing data after casewise deletion for some variables in the econometric analyses.

The analysis focuses on the effect of remittances on poverty and inter-household income inequality. According to Adams (2011), there are at least four methodological problems that confront any economic work on international migration: simultaneity, reverse causality, selection bias and omitted variable bias. Yet, appropriate solutions, although available in theory, are difficult to implement in practice. For instance, experimental designs are almost impossible to obtain, and panel data are rarely available. Sample selection procedures and the use of instrumental variables are the most commonly used solutions. Instrumental variables may, in theory, remove many of the biases that arise from endogeneity, selection bias and omitted variables, but the difficulty comes in specifying good instruments. A fully convincing set of suitable instruments in a migration regime is not available yet; there are many different arguments put forward to support the choice of particular instruments but better conceived instruments are generally lacking (Miluka et al. 2010; Davis et al. 2010).

Furthermore, analytical results on remittances and income depend on whether remittances are treated as a substitute for local earnings or as an exogenous transfer. Thus, this touches on the question of whether or not the opportunity costs of migration are 
taken into account. This issue can be addressed by constructing a counterfactual situation reflecting what the status of a migrant household would have been had that household not involved itself in migration (McKenzie and Sasin 2007). In our analysis, we apply the method of PSM to estimate counterfactual incomes from which the poverty and inequality effects are assessed. PSM estimators have been developed to correct for non-random (self-)selection and to pair treated observations (with migrants) with similar controls (without migrants). The outcome of the control observation can be interpreted as the counterfactual income of the treated observations (in the absence of treatment) (Jimenez-Soto and Brown 2012).

The applied PSM methodology consists of the following steps. First, a logit or probit model of migrant and non-migrant households is estimated. The parameters of this model, that should be unaffected by treatment and fulfil the unconfoundedness condition, are used in the second step to predict the propensity score, which expresses the predicted probability of a household engaging in migration ${ }^{4}$. Third, migrant and nonmigrant households are matched; the observed income of the matched non-migrant household is imputed as the counterfactual income of the migrant household.

In our analysis, we use a set of socio-economic variables to estimate a logit model on the treatment variable (migrant households) (Additional file 1: Tables S1 and S2). For the PSM procedure we use the psmatch2 and teffects psmatch Stata modules; for the choice of variables we relied on recommendations given by Caliendo and Kopeinig 2008). The method by which the matched pairs were formed was the three nearest neighbour procedure allowing replacement. The robustness of the results was tested along different specifications including caliper, radius and kernel matching. Tests for balance and common support were undertaken. Successful matching was checked along the bias reduction and t-test (Additional file 1: Table S3), and Pseudo R2 (Additional file 1: Table S4) (Caliendo and Kopeinig 2008). Furthermore, overlap must be given to ensure the common support assumption. Additional file 1: Figure S1 presents visual analysis results of propensity score distributions. Since the bootstrap standard errors for PSM estimators are not in general found to be valid, we rely on standard errors obtained from Stata teffects psmatch for the calculation of treatment effects; the underlying methodology is based on the work of Abadie and Imbens (2012). Rosenbaum bounds are calculated to test the sensitivity of estimated treatment effects with respect to unobservables (Additional file 1: Table S5).

The derived counterfactual incomes are used in the analysis of poverty and inequality effects as well as in a logit model in which we aim to explore further the success factors of migration.

Poverty is measured not only along income groups (tertiles and quintiles), but also by three standard poverty measures: (1) the headcount index; (2) the poverty deficit index; and (3) the poverty severity index (Foster et al. 1984). The three poverty measures by Foster et al. (1984) are described by

$$
P(\alpha)=\frac{1}{n} \sum_{i=1}^{m}\left[\max \left(\frac{z-c_{i}}{z}, 0\right)\right]^{\alpha},
$$

where $z$ is the poverty line, $c_{i}$ is the income of the individual $i, n$ is the total number of individuals and $m$ is the number of poor individuals. The parameter $\alpha$ changes 
depending on the poverty measure. If $\alpha$ is set equal to 0 , we obtain $\mathrm{P}(0)$, that is, the headcount index indicating the proportion of the poor below the poverty line. $\mathrm{P}(1)$ displays the poverty deficit, a measure that takes into account how far the poor, on average, fall below the poverty line. Finally, if $\alpha$ is set equal to 2, we obtain $\mathrm{P}(2)$, called the poverty severity measure, which captures the difference in the severity of poverty by giving more weight to the poorest. Thus, poverty severity accounts for income differences (World Bank 2000; Coudouel et al. 2000).

The choice of poverty lines is a critical issue, especially if policy conclusions are drawn. Ravallion (1998) discusses alternative approaches to setting and implementing poverty lines. In general, absolute poverty lines, which have a fixed real value over time and space, are preferable to relative poverty lines that rise with the average income and expenditure levels. Poverty lines may be set according to food intake or cost-of-basicneeds. In addition, subjective perceptions are sometimes used to set poverty lines. In our approach we show results for several poverty lines. As a measure of absolute and extreme poverty we use a line that was suggested by the World Bank and SOK (2011) for Kosovo. It is calculated based on a cost-of-basic-needs approach. This poverty line lies somewhat below the commonly used 2-\$ per day- line suggested for Eastern European countries (Alam et al. 2005). Another absolute poverty line that has been used for this region is set at US $\$ 4.30$ per day. This is supposed to reflect a vulnerability threshold in order to identify households which are not suffering absolute material deprivation, but are vulnerable to poverty. Although it seems somewhat arbitrary, it does bear some relationship to empirically observed vulnerability to poverty (Alam et al. 2005). Finally we also present a relative poverty line which is used in, for example, Eurostat statistics. However, we stress that absolute poverty lines are certainly more relevant in the context of our study.

Poverty analyses often refer to adjusted household sizes which are used to calculate per capita incomes that consider economies of scale. Economies of scale arise in many ways in a family, for example by sharing certain expenditures such as housing or a car. There are different methods for estimating equivalence scales. Here we use figures that reflect the so-called modified OECD equivalence scale which is also used by Eurostat. It assigns the coefficient 1 to the household head, 0.5 to other adults in the household, and 0.3 to children under the age of 16 .

The effect of certain income sources on income distribution can be determined by Gini coefficients ${ }^{5}$ in two ways (Reardon et al. 2000). The most common method is the comparison of a Gini coefficient for all incomes with another Gini coefficient that is calculated excluding the income source of interest (in our case, remittance income). If the latter is smaller than the Gini based on total income, this income source has a negative effect on the income distribution, and vice versa. In addition, decomposition according to different income sources allows conclusions to be drawn regarding the relative distribution effect of certain sources. The contribution of each income source is the product of a concentration coefficient for that income source and the fraction of that income source in total income (Shorrocks 1982; World Bank 2000). Formally $G_{k}^{*}$, the concentration coefficient for income component $k$, is given by

$$
G_{k}^{*}=\frac{2}{\mu n^{2}} \sum_{i=1}^{n}\left(r_{i}-\frac{n+1}{2}\right) y_{k, i},
$$


where $y_{k, i}$ is the component $k$ of the income of household $i$. The mean total income is denoted by $\mu$, and $r_{i}$ is the household's $i$ rank in the ranking of all incomes. The Gini coefficient is a weighted sum of the concentration coefficients $G^{*}$

$$
G=\sum_{k=1}^{K} \frac{\mu_{k}}{\mu} G_{k}^{*}=\sum_{k=1}^{K} S_{k} G_{k}^{*}
$$

where $S_{k}=\mu_{k} / \mu$ is the share of component $k$ in total income. The percentage contribution of income source $k$ to total income equality is found to be

$$
P_{K}=S_{k} \frac{G_{k}^{*}}{G} \times 100 \% \text {. }
$$

The marginal contribution of each income source $k$ to inequality can be described by an elasticity of the Gini coefficient, which is given by Lerman and Yitzhaki (1994) as

$$
\in_{G, S_{k}}=\frac{S_{k}\left(G_{k}^{*}-G\right)}{G}
$$

\section{Descriptive statistics: a comparison of migrant and non-migrant households}

The objective of this section is to briefly introduce the rural Kosovar household to the reader. Bearing in mind our research question, we present important differences in the demographic- and income-related variables of migrant and non-migrant households in the sample that also inform the main results in Section 5.

Rural households in Kosovo are typically big. The 1,727 rural households of the KRS have, on average, five family members (with considerable variation in the household size) ${ }^{6}$. The average age of the household head is 50 years. Around $28 \%$ of the households are categorised as migrant households, meaning that they have at least one family member living abroad; on average the number of migrants is 2.5 . About $60 \%$ of these migrant households receive remittances. In the overall sample around $17 \%$ receive remittances. Table 1 presents socio-economic variables of migrant and non-migrant rural households; the non-parametric Kruskal-Wallis test, indicating whether the mean, frequency or median are equally based on calculated ranks, is used to test for significant differences.

Migration depends on the availability of work force in a household. Therefore it is no surprise that migrant households tend to be bigger, however their dependency ratio is also slightly higher than non-migrant households $(0.60 \text { versus } 0.49)^{7}$. Education is sometimes mentioned as a key door opener for migration activities. But although the educational attainment of the rural household heads is generally high (almost eleven years of schooling), it does not differ significantly between migrant and non-migrant households. The same is true for the highest level of education within the household ${ }^{8}$.

The average annual household income (excluding remittances) lies at around $€ 4,800$ per annum (Table 1). When remittances are not considered in the household income, differences between migrant and non-migrant households are not significant; if remittances are included, migrant households have significantly higher household and per capita incomes. Per capita incomes that include remittances, calculated based on equivalised household sizes (see Section 3), are 70\% higher for migrant households than for non-migrant households ( $€ 2,633$ versus $€ 1,840$ ). 
Table 1 Socio-economic characteristics of rural households with and without migrants

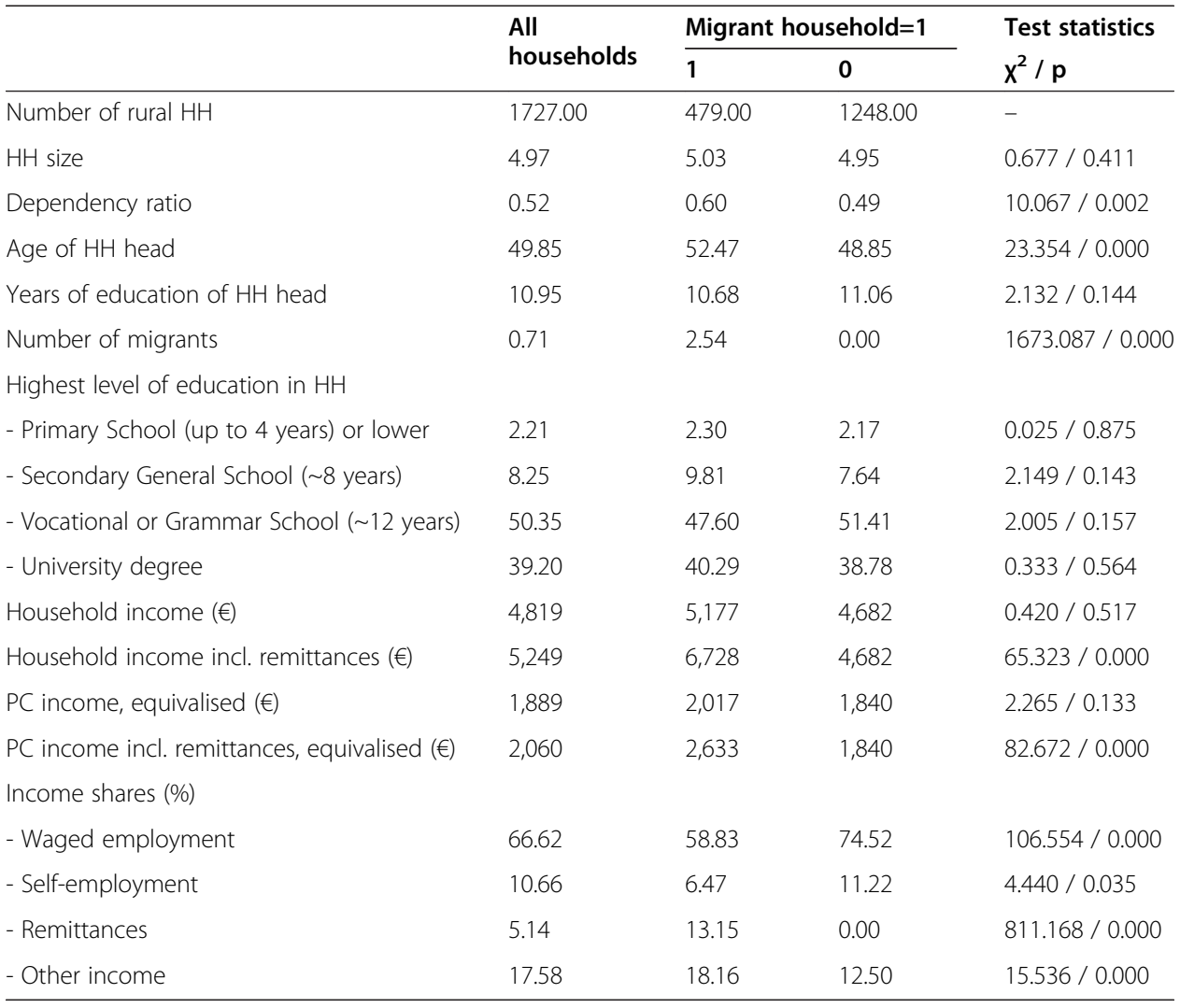

Source: Own calculation based on KRS 2010 data.

Note: $\mathrm{N}=1,727$ rural households; $\mathrm{HH}=$ household, $\mathrm{PC}=$ per capita.

Test statistics refer to a Kruskal-Wallis-Test.

The major share of rural incomes, around two thirds, stems from waged employment. Indeed, 70\% of all rural households have waged employment as their primary income source. The income share is lower for migrant households (59\%). Remittances make up on average $13 \%$ of their income. Overall, the share of remittances in all households lies at around $5 \% ;{ }^{9}$ remittances make up the largest income share in less than $4 \%$ of the rural households ${ }^{10}$. Self-employment is the primary income source of around $11 \%$ of all rural households. It plays a slightly bigger role in the income portfolio of non-migrant households (11\% income share versus $6 \%$ in migrant households). Thus, it does not seem that remittances are a key to open up business opportunities (see also Section 2). Despite the extraordinary agro-ecological potential for agricultural activities, rural households rely to a relatively low degree on farm incomes (unfortunately not included in the KRS database). National statistics show that only around $6 \%$ of Kosovar households indicate that farm incomes are their major income source, and the contribution to overall individual incomes is only 1\% (Statistical Office of Kosovo 2010). Even for farm households this share at $13 \%$ is surprisingly low, most likely due to the small average farm size of less than three hectares and low levels of market orientation (Möllers et al. 2013).

The category 'other income' in Table 1 is mainly derived from pensions or social payments. At the national level, social welfare benefits account for $2 \%$ of individual incomes, pensions from Kosovo for $6 \%$ and pensions from abroad for $4 \%$ of the 
incomes (Statistical Office of Kosovo 2010). In our KRS data these contribute a surprisingly large share (18\%) to total rural household incomes (Table 1); around 14\% indicate that 'other income' is their main source of income. The significant difference between migrant and non-migrant households is probably due to former or current migrants having access to pensions from abroad.

In a nutshell, although migrant households do not seem to be better educated, they enjoy higher incomes. The absolute income difference is significant when remittances are considered. For both migrant and non-migrant households waged employment is the most important income source. Migrant households rely less on self-employment, but more on transfers such as from remittances, pensions or social assistance.

\section{Main findings: effects of remittances on poverty and inequality in Rural Kosovo}

In this section we provide evidence about the welfare effects of remittances on rural households. In the previous section we showed that remittances contribute significantly to absolute incomes of migrant households. Now we look at the overall poverty situation by presenting results on income groups and poverty indices. This is followed by an inequality analysis. Finally, with the aim of understanding how poverty reduction could be addressed more effectively through migration, we explore factors that determine migration success.

Effects on poverty and inequality depend on the number of recipients, absolute remittances amounts, and on who sends migrants and receives remittances. This last aspect, addressing the question of whether proportionally more migrants come from lower or higher income groups (Milanovic 1987) and how these income groups are characterised, is presented in Table 2; we distinguish three income classes (tertiles), where the first tertile is the income class with the lowest per capita income and the third tertile is the richest group.

Indeed, poorer households have significantly fewer migrants, and less than $10 \%$ receive remittances at all (Table 2). In particular, the number of migrant households (with at least one migrant) is significantly higher in wealthier households ${ }^{11}$. Accordingly, the percentage contribution of remittances to the income portfolios rises from the poor to the wealthy tertile. In the wealthiest income class more than one quarter of households receive remittances; for $7 \%$ of households in the third tertile remittances are their main income source. The absolute value that remittances add to per capita incomes leads to an income rise of $13 \%$ compared to $3-4 \%$ in the other tertiles. Whether these households have climbed the ladder towards this tertile or were better off in the first place is an important question. One indication for the amount of upward shifting is shown in a comparison for tertile membership in a counterfactual situation (where the observed income of the matched non-migrant household is imputed as counterfactual income of the migrant household) and the actual situation: 6\% moved from tertile 1 in the counterfactual scenario towards tertile 2 in the actual scenario. Almost $20 \%$ of wealthy households in tertile 3 come from the counterfactual tertiles 1 and 2.

An indicator for the existence of income inequality within rural Kosovar households is shown in Table 2 in the fact that the richest income group earns more than half of all incomes, while the share of the poorest tertile in all household incomes is only $16 \%$. 
Table 2 Socio-economic characteristics according to income classes

\begin{tabular}{|c|c|c|c|c|c|}
\hline & \multirow{2}{*}{$\begin{array}{l}\text { All } \\
\text { households }\end{array}$} & \multicolumn{3}{|c|}{ Income class (tertile) } & \multirow{2}{*}{$\begin{array}{l}\text { Test statistics } \\
\mathrm{x}^{2} / \mathrm{p}\end{array}$} \\
\hline & & 1 & 2 & 3 & \\
\hline Number of rural $\mathrm{HH}$ & 1727.00 & 576.00 & 575.00 & 576.00 & - \\
\hline Share of remittances receiving $\mathrm{HH}$ in \% & 16.79 & 9.38 & 14.43 & 26.56 & $72.427 / 0.000$ \\
\hline HH size & 4.97 & 5.60 & 4.90 & 4.43 & 0.049 / 0.976 \\
\hline Dependency ratio & 0.52 & 0.65 & 0.47 & 0.43 & $3.078 / 0.215$ \\
\hline Age of $\mathrm{HH}$ head & 49.85 & 50.10 & 50.13 & 49.32 & $1.766 / 0.414$ \\
\hline Number of migrants & 0.71 & 0.42 & 0.64 & 1.06 & $3.998 / 0.135$ \\
\hline Share of $\mathrm{HH}$ with at least one migrant & 27.74 & 17.19 & 25.39 & 40.63 & $81.249 / 0.000$ \\
\hline Years of education of $\mathrm{HH}$ head & 10.95 & 10.15 & 11.18 & 11.52 & $4.574 / 0.102$ \\
\hline \multicolumn{6}{|l|}{ Highest level of education in $\mathrm{HH}$ in \% } \\
\hline - Primary School (up to 4 years) or lower & 2.21 & 4.20 & 1.39 & 1.04 & $6.171 / 0.046$ \\
\hline - Secondary General School ( $\sim 8$ years) & 8.25 & 13.46 & 5.39 & 5.91 & 49.644 / 0.000 \\
\hline - Vocational or Grammar School ( 12 years) & 50.35 & 51.75 & 52.87 & 46.43 & $4.087 / 0.130$ \\
\hline - University degree & 39.20 & 30.59 & 40.35 & 46.61 & $28.244 / 0.000$ \\
\hline Household income $(€)$ & 4,819 & 2,506 & 4,255 & 7,695 & $8.427 / 0.015$ \\
\hline Household income incl. remittances (€) & 5,249 & 2,577 & 4,469 & 8,700 & $8.570 / 0.014$ \\
\hline PC income, equivalised $(€)$ & 1,889 & 852 & 1,599 & 3,216 & $9.020 / 0.011$ \\
\hline PC income incl. remittances, equivalised $(€)$ & 2,060 & 877 & 1,667 & 3,637 & 9.449 / 0.009 \\
\hline \multicolumn{6}{|l|}{ Income shares (\%) } \\
\hline - Waged employment & 66.62 & 54.07 & 73.28 & 72.50 & $2.038 / 0.361$ \\
\hline - Self-employment & 10.66 & 14.44 & 9.96 & 7.59 & $3.667 / 0.160$ \\
\hline - Remittances & 5.14 & 2.59 & 4.05 & 8.77 & $6.000 / 0.050$ \\
\hline - Other income & 17.58 & 28.89 & 12.72 & 11.14 & $2.352 / 0.308$ \\
\hline $\mathrm{HH}$ with remittances as main income source (\%) & 3.65 & 2.08 & 1.74 & 7.12 & $29.688 / 0.000$ \\
\hline Household spending (€ per month) & 130.80 & 83.28 & 130.10 & 179.66 & \\
\hline Household food expenditures (\%) & 40.63 & 44.56 & 40.70 & 38.28 & \\
\hline Share in all household incomes (\%) & 100.00 & 16.37 & 28.35 & 55.28 & \\
\hline $\begin{array}{l}\text { Upward shift compared to tertile based on } \\
\text { counterfactual migrant incomes }\end{array}$ & 8.51 & - & 6.09 & 19.44 & \\
\hline
\end{tabular}

Source: Own calculation based on KRS 2010 data.

Note: $\mathrm{N}=1,727$ rural households; Tertile 1 = Income class with the lowest per capita income (incl. remittances) etc. $\mathrm{HH}=$ household, $\mathrm{PC}=$ per capita.

The test statistics refer to a Kruskal-Wallis-Test.

Furthermore, the household income (including remittances) of the middle tertile is around $70 \%$ higher than that of the first, while the richest group has more than three times as much as the first, and almost double the income compared to the middle tertile. Differences in per capita incomes are even higher. One reason for the income differences may be seen in the better educational attainment in the higher tertiles: the number of years in education of the household head increases from the poor to the better-off. The wealthiest income class has a particularly high share of university education (this indicator looks at the highest level of education in the household). Poor households are represented with a significantly higher share in primary and secondary education and a lower share in university degrees. 
Table 3 presents three common income based poverty measures calculated on the basis of three different poverty lines ${ }^{12}$. We have chosen two absolute poverty lines, and one relative poverty line (see Section 3).

The consumption based poverty line of $€ 1.55$ per day in 2009 prices that is used by the World Bank and SOK (2011) seems, from our point of view, very low. This poverty line reflects the social assistance level that a person gets in Kosovo, $€ 40$ per month (Statistical Office of Kosovo 2010), an amount which is, according to what we saw during our survey work, hard to live off in the country. It is also far below the average expenditure of the poorest tertile of the KRS rural households of around $€ 83$ per person per month (Table 2). Thus it clearly reflects extreme poverty. According to this poverty line, $7 \%$ of the rural sample are considered extremely poor. The poverty deficit, defined as the average distance of the poor to the poverty line, is $2 \%$. The measure of poverty severity considers income differences by giving more weight to the poorest. In other words, greater weight is given to households that are further away from the poverty line. It lies at $1 \%$ for this extreme poverty line.

Vulnerability to poverty is reflected in the PPP-US\$ 4.30 line. Here, the vulnerability incidence lies at $45 \%$. For the PPP-US\$ 4.30 line the poverty deficit (16\%) and poverty severity (8\%) are slightly higher than for the measure of extreme poverty. The chosen relative poverty line of $60 \%$ of the median ${ }^{13}$ of the equivalised per capita income is below the PPP-US\$ 4.30 line. It results in a poverty incidence of $20 \%$; poverty deficit is at $6 \%$ and poverty severity at $3 \%$.

The impact of migration and remittances on poverty is depicted in the last two columns of Table 3. Obviously, results depend on the poverty line. Differences between a 'naïve' comparison of a headcount index calculated based on incomes without considering remittances and the counterfactual income approach are relatively small. Still, the expected overestimation of the positive impact of remittances on poverty reduction is visible $^{14}$. Overall, poverty levels would rise between $0 \%$ and $3 \%$ if households were not supported by their family members living abroad (based on counterfactual incomes). Extreme poverty seems to be unaffected by remittances. This may be explained by the selfselection of migrants from the middle and higher income groups. Poverty reduction based on the PPP-US\$ 4.30 line from 0.48 and 0.45 reflects an absolute number of 200 rural migrant households ( $41 \%$ of all migrant households) which are lifted out of poverty due to

Table 3 Poverty in rural Kosovo

\begin{tabular}{lllllll}
\hline & $\begin{array}{l}\text { Yearly } \\
\text { income } \\
(€)\end{array}$ & $\begin{array}{l}\text { Headcount- } \\
\text { index }\end{array}$ & $\begin{array}{l}\text { Poverty } \\
\text { deficit }\end{array}$ & $\begin{array}{l}\text { Poverty } \\
\text { severity }\end{array}$ & $\begin{array}{l}\text { Headcount index } \\
\text { Without } \\
\text { remittances }\end{array}$ & $\begin{array}{l}\text { Counterfactual } \\
\text { incomes }\end{array}$ \\
\hline Absolute poverty line & & & & & & \\
$€ 1.55$ line, 2009 prices* $^{*}$ & 566 & 0.07 & 0.02 & 0.01 & 0.09 & 0.07 \\
PPP-US\$ 4.30 line & 1,453 & 0.45 & 0.16 & 0.08 & 0.51 & 0.48 \\
Relative poverty line & & & 0.06 & 0.03 & 0.22 & 0.21 \\
$60 \%$ of sample median** & 930 & 0.20 & 0.06 & & \\
\hline
\end{tabular}

Source: Own calculation based on KRS 2010 data.

$\mathrm{N}=8,591$ rural household members from both subgroups with and without migrants

*Absolute poverty line used by the World Bank (2011) for Kosovo on the basis of a cost-of-basic needs approach for 2009.

**This poverty line corresponds to $60 \%$ of the median equivalised per capita income within the sample. 
Table 4 Average treatment effect on migrant households

\begin{tabular}{lllllll}
\hline Variable & Sample & Treated & Controls & Difference & Std. Err. & T-stat \\
\hline Per capita income (pcincequrem) & Unmatched & 2578.85378 & 1834.50793 & 744.345851 & 113.049411 & 6.58 \\
& ATT & 1834.50793 & 1893.62923 & 685.224549 & 160.721832 & 4.26 \\
\hline Test for significance based on Al robust Std. Err. ${ }^{* * *}$ according to Abadie and & 687.5878 & 157.1407 & 4.38 \\
Imbens (2012) & & & & & \\
\hline
\end{tabular}

Source: Own calculation based on KRS 2010 data.

remittances. For the relative poverty line we find that $85(18 \%)$ of the migrant households are raised above the threshold due to remittances.

The effect of migration on migrant households is also shown in the average treatment effect on the treated that results from PSM analysis. Migration leads to an average income increase of around $€ 690$ per year in migrant households (Table 4).

Table 5 depicts rural Gini coefficients and addresses the question of whether remittances play a role with regards to income inequality. The income distribution was calculated for total equivalised per capita incomes, for per capita incomes excluding remittances, and for the counterfactual scenario. The national Gini coefficient for the year 2005 was about 0.30 (World Bank 2007a). The Gini coefficient of 0.37 for the sample indicates a slightly higher inequality for our rural population. If remittances are not considered ('naïve' approach), the Gini coefficient goes down slightly to 0.36 . Using counterfactual incomes, the Gini is 0.35 . The examination of partial coefficients calculated on the basis of decomposed Gini coefficients confirms this tendency towards an un-equalising effect of remittances (positive elasticity in brackets in the lower part of Table 5). This is in line with the fact that remittances are the most unevenly distributed income source and, as we have seen, tend to be concentrated in richer income groups. The elasticity figure indicates that a $1 \%$ increase in remittances would lead to a $6.9 \%$ increase in the Gini coefficient. Yet, if we assume that migrants tend to be concentrated in the upper segments of the income distribution, the effect is most likely overestimated (see Acosta et al. 2008). Similarly to remittances, waged employment increases income inequality. Incomes from self-employment and 'other income' decrease inequality: their elasticities are negative.

We have seen that migration lifts a large proportion of migrant households out of poverty, but not all migrant households are able to achieve a significant upward shift in

Table 5 Income distribution and remittances

\begin{tabular}{ll}
\hline Gini coefficient & \\
\hline - on the basis of equivalised per capita incomes & 0.37 \\
- remittances excluded & 0.36 \\
- using counterfactual incomes & 0.35 \\
Decomposed Gini coefficients (elasticity in brackets) & $0.38(0.029)$ \\
- on the basis of waged incomes & $0.19(-0.044)$ \\
- on the basis of self-employment & $0.67(0.069)$ \\
- on the basis of remittances & $0.22(-0.054)$ \\
- on the basis of other incomes &
\end{tabular}

Source: Own calculation based on KRS 2010 data.

Note: $\mathrm{N}=1,727$ rural households from both subgroups with and without migrants. 
incomes. Based on a logit regression we aim to show how a set of variables is related to the success of rural households' migration activities in Kosovo. An underlying hypothesis is that households which can increase their income enough to move at least one quintile upwards differ significantly in their socioeconomic variables. We measure this upward movement as a positive change between the quintile based on counterfactual migrant household income compared to the actual income quintile. The dummy turns one for this positive quintile shift. For households that start from the highest quintile the dummy turns one if they reach a $20 \%$ increase in incomes compared to the counterfactual situation. We use a set of classical socio-economic independent variables as typically used in poverty analyses and regress them on our sample of 479 migrant households (389 after casewise deletion). The model presented in Table 6 has an overall good fit. Descriptive statistics can be found in the Additional file 1: Table S6.

A positive shift in quintiles is reached by 185 successful migrant households (48\%). These households are characterised by a higher educational level, i.e. a university

Table 6 Logit regression on successful migration (quintile upward move)

\begin{tabular}{|c|c|c|c|c|c|c|}
\hline \multirow{2}{*}{$\begin{array}{l}\text { Independent variables } \\
\text { agehhh }\end{array}$} & \multirow{2}{*}{$\begin{array}{l}\text { Coefficient } \\
0.171\end{array}$} & \multirow{2}{*}{$\frac{\text { Std. Err. }}{0.067}$} & \multirow{2}{*}{$\frac{\text { Sig. }}{0.011}$} & \multirow{2}{*}{$\frac{\operatorname{Exp}(B)}{1.186}$} & \multicolumn{2}{|c|}{$95 \%$ Conf. Interval } \\
\hline & & & & & 1.039 & 1.353 \\
\hline agehhh2 & -0.002 & 0.001 & 0.006 & 0.998 & 0.997 & 0.999 \\
\hline genderhhh & 0.607 & 0.419 & 0.148 & 1.834 & 0.807 & 4.170 \\
\hline eduyhhh & -0.052 & 0.053 & 0.328 & 0.949 & 0.856 & 1.053 \\
\hline unemployed & -0.720 & 0.329 & 0.028 & 0.487 & 0.255 & 0.927 \\
\hline Albanian & 0.702 & 0.387 & 0.069 & 2.018 & 0.946 & 4.308 \\
\hline maxeduhigh & 0.796 & 0.326 & 0.015 & 2.216 & 1.170 & 4.198 \\
\hline depratio & -0.725 & 0.257 & 0.005 & 0.484 & 0.293 & 0.801 \\
\hline sumofactive & -0.437 & 0.112 & 0.000 & 0.646 & 0.519 & 0.804 \\
\hline nomigr & -0.020 & 0.068 & 0.765 & 0.980 & 0.857 & 1.120 \\
\hline munrem2009_2 & 0.000 & 0.000 & 0.000 & 1.000 & 1.000 & 1.000 \\
\hline rem & 0.016 & 0.006 & 0.010 & 1.017 & 1.004 & 1.029 \\
\hline cfpcinc & -0.002 & 0.000 & 0.000 & 0.998 & 0.998 & 0.999 \\
\hline Prishtina & -0.021 & 0.712 & 0.976 & 0.979 & 0.243 & 3.949 \\
\hline Mitrovica & -0.763 & 0.758 & 0.314 & 0.466 & 0.105 & 2.062 \\
\hline Peje & -0.763 & 0.768 & 0.320 & 0.466 & 0.104 & 2.098 \\
\hline Gjilan & -0.612 & 0.768 & 0.426 & 0.542 & 0.120 & 2.443 \\
\hline Prizren & -0.056 & 0.762 & 0.942 & 0.946 & 0.212 & 4.209 \\
\hline Ferizaj & -0.067 & 0.748 & 0.928 & 0.935 & 0.216 & 4.049 \\
\hline constant & -0.037 & 1.909 & 0.985 & 0.964 & & \\
\hline
\end{tabular}

Number of observations $=389$

migrant households.

$\operatorname{chi} 2(19)=175.063$.

Prob > chi $2=0.000$.

Nagelkerke R2 $=0.484$.

Hosmer Lemeshow chi2 (8) $=4.324$.

Prob > chi $2=0.827$.

Source: Own calculation based on KRS 2010 data.

Note: Dependent variable: successful migration (dummy that turns 1 if household moves upwards to a higher quintile compared to the counterfactual situation; for migrant household starting from the highest quintile a $20 \%$ increase in incomes turns the dummy to 1 ). 
degree of some kind within the household. Interestingly, the variable depicting years of education of the household head is not significant. An upward movement in quintiles is further related to the age of the household head. The probability for the move increases with age, but decreases again from some point on. It is higher for ethnic Albanian households. A dummy variable indicating whether a household head is unemployed or not is significant too: unsurprisingly, unemployment has a negative influence on migration success. With regard to the household composition we find that an increasing number of dependents lowers the probability for a positive shift. However, the same is true for an increasing number of household members of working age. Thus it seems that smaller households with a small share of dependents are best off in terms of achieving the move to a higher quintile. While the regional dummies give no significant results, a variable that displays the squared average absolute remittances received in a municipality is significant. Thus, very high municipality averages are linked to the successful migration of individual migrant households as well. The share of remittances in the current household income increases the probability of moving up the quintiles. Interestingly, the counterfactual income is significant with a negative impact on migration success. We interpret this as follows: our success indicator, an upward shift between quintiles, is comparatively easier to reach for poorer household. This is due to the lower absolute income rise that is needed for the move between lower quintiles compared to the move between the fourth and fifth quintile in particular.

Summing up our main findings, we show that migration has the expected positive effect on rural incomes. However, the poorest tend to benefit less. For the extremely poor, we find no impact on poverty reduction at all. This is explained by the fact that migrants and remittances are more often found in wealthier and better educated households. According to our counterfactual scenario, migrant households increase their income significantly by almost $€ 700$ per year. However, not all migrant households are labelled successful. Those who are able to climb the income ladder often come from small households with not many dependent members in the lower income groups. They are characterised by higher education. The share of remittances in their household income is high, and a location in a municipality with high remittances increases the probability for success. Effects on income distribution point towards an increase in inequality through remittances, which again might be attributed to the fact that remittances tend to flow towards wealthier households and do not reach the poorest.

\section{Conclusion}

In Kosovo a saying goes, a family needs 'one son for the family, who stays at home, one for migration, who works abroad, and one for the mother country'. Indeed, many rural Kosovar households are involved in migration and they benefit from remittances. But is 'one son for migration' really needed in rural Kosovo to be able to make ends meet? Are remittances helping to find a pathway out of poverty? We cannot give a definite answer to these questions, because this would need longitudinal data, but our counterfactual scenarios strongly indicate that remittances are indeed important in the fight against poverty in rural Kosovar households.

First, we show that migrant households have higher absolute incomes, and the share of remittances in the income of migrant households is significant (13\%). Second, poverty indicators calculated based on counterfactual incomes show that, depending on 
the poverty line chosen, a considerable share of $18 \%$ or $41 \%$ respectively of migrant families are no longer poor due to their access to remittances. However, the effect is not seen to apply to the extremely poor who generally have less access to remittances. Third, with regard to distributional effects, we find (based on decomposition and a comparison with counterfactual incomes) that migration makes the income distribution more unequal. This can be taken as a hint that those who do not take part in migration activities and do not benefit from remittances fall behind.

According to our counterfactual scenario, migrant households increase their income significantly by almost $€ 700$ per year. However, not all migrant households are able to climb the income ladder. Successful migration certainly depends on various factors, some of them complex or even unobservable. Starting from a set of classical socio-economic factors, we show that the household structure and the wealth status are decisive for the migration outcome. Migrant households which are successful are further characterised by significantly higher education levels than migrant households with lower educational levels. This is not the case for migrant households as a whole where, compared with non-migrant households, differences in education are not significant. This results from the fact that better education is typically found in the upper income tertile, where successful migrant households rather do not come from. We therefore conclude that education is one key for making migration a pathway out of poverty: it allows families to climb the income ladder through migration. Certainly other factors might have an important influence on migration outcomes and thus on poverty too. Our analysis is limited at this stage as we would have liked to include additional relevant variables such as risk behaviour or attitudes of the migrant.

With regard to policy conclusions, first, we stress that the poorest seem to benefit least from migration. Therefore it is necessary to monitor the income distribution. Only if trickle down effects materialise may a drop in income equality be avoided in the longer term. Social security policies are important in supporting those who are most vulnerable and excluded from migration benefits. Second, our analysis shows that migration is not solely beneficial for better off households: in fact within the group of migrant households, poorer households in particular are able to turn migration into success. Making migration a success story is key to poverty reduction based on remittances. Education seems to be among the most important factors to achieve this.

\section{Endnotes}

${ }^{1}$ The focus on rural households is justified because it is known that they tend to benefit more from remittances than urban households, and are also more affected by poverty (Haxhikadrija 2009).

${ }^{2}$ However, Göbel (2013) finds for Ecuador that remittance inflows increase expenditures on education, health, and housing.

${ }^{3}$ The subsample refers to the subset of rural households with complete income data. Households with more than ten household members are not included due to missing data in the KRS database (for these households it is not possible to calculate the correct per capita incomes that are needed for the analyses).

${ }^{4}$ PSM assumes that the treatment satisfies some form of exogeneity, meaning that the selection is on observables. The assumption of unconfoundedness implies that systematic differences in outcomes between treated and untreated units with the same value for covariates are attributable to treatment. Thus, it relies on a set of observable variables that 
captures all relevant differences between the treated and control group so that the nontreatment outcome is independent of the treatment status, conditional on those characteristics; the possible existence of unobservables correlated with the migration decision is a limitation to the application of the method (Caliendo and Kopeinig 2008, Jimenez-Soto and Brown 2012, Imbens and Rubin 2014).

${ }^{5}$ The Gini coefficient is the most widely used measure of income distribution. Its value varies between zero and one, with zero indicating a perfectly equal income distribution. The higher a Gini coefficient is, the more unequally incomes are distributed. Gini coefficients between 0.25 and 0.35 are considered 'reasonable', while coefficients higher than 0.5 indicate that income distribution is seriously unbalanced (Ellis 2000).

${ }^{6}$ The average household size of five household members is underestimated: it does not include households with more than ten household members because they are excluded from the sample due to missing data in the KRS 2010 database (see above).

${ }^{7}$ Pure pensioner households are excluded because dependency ratios cannot be calculated.

${ }^{8}$ Pastore et al. (2013) point at significant gender differences: young women tend to have a lower level of education and are less likely to be employed.

${ }^{9}$ Milanovic (1987) in his study of Yugoslav households provides remittances income shares for the 1973, 1978 and 1983 in which the percentages for Yugoslavia were given as between $3 \%$ and $5 \%$. He stresses that remittances are consistently higher among farm households (10\%-15\%).

10 The Statistical Office of Kosovo (2010) estimates this share to be around $10 \%$ in Kosovo.

11 This is also the case if tertiles are calculated based on counterfactual incomes derived from PSM.

${ }^{12}$ Although it is often argued that consumption-based poverty indicators are preferable, we concentrate in our analysis on income-based indicators. While consumption and income differ only moderately for the first two tertiles, the consumption data and income data are strikingly different for the third tertile - probably due to higher investment and saving activities that are not depicted in the KRS database.

${ }^{13}$ We use the sample median income, a number that is expected to be somewhat below the national median because we look at rural households only.

${ }^{14}$ Acosta et al. (2008) confirm this on an empirical basis for a number of Latin American countries. They point out that when no imputations are made for the income of remittance senders, countries where recipients are concentrated at the bottom of the distribution of non-remittance income exhibit much higher reductions in poverty headcounts attributable to remittances. Nonetheless, they stress that the effects of remittances are in either case far from negligible.

\section{Additional file}

Additional file 1: Table S1. Descriptive statistics of variables in the PSM logit model. Table S2: PSM logit results - psmatch2: NN (3). Table S3: Testing the balance of covariates and absolute bias reduction. Table S4: R2 of raw and matched model. Table S5: Rosenbaum bounds test for sensitivity. Table S6: Descriptive statistics of variables in the logit model on successful migration. Figure S1: Overlap graph. 
Nations Development Programme; USAID: United States Agency for International Development; US\$: US dollar; SOK: Statistical Office of Kosovo.

\section{Competing interests}

The IZA Journal of Labour and Development is committed to the IZA Guiding Principles of Research Integrity. The authors declare that they observed these principles.

\section{Acknowledgements}

The authors wish to acknowledge very useful comments from the anonymous referee. We are also thankful to the UNDP for the provision of the data of the Kosovo Remittance Study 2010.

Responsible editor: Hartmut Lehmann

\section{Received: 15 October 2013 Accepted: 5 June 2014}

\section{Published: 29 Sep 2014}

\section{References}

Abadie A, Imbens GW (2012) Matching on the estimated propensity score. Harvard University and National Bureau of Economic Research. http://www.hks.harvard.edu/fs/aabadie/pscore.pdf, 18.6.2014

Acosta P, Calderón C, Fajnzylber P, Lopez H (2008) What is the impact of international remittances on poverty and inequality in Latin America? World Dev 36:89-114

Adams RH (2011) Evaluating the economic impact of international remittances on developing countries using household surveys: a literature review. J Dev Stud 47(6):809-828

Adams RH, Page J (2005) International Migration, Remittances and Poverty in Developing Countries. In: MAIMBO SM, RATHA D (eds) Remittances - Development Impact and Future Prospects. The World Bank, Washington DC, USA

Adams RH, Cuecuecha A, Page J (2008) The Impact of Remittances on Poverty and Inequality in Ghana, Policy Research Working Paper No. 4732. The World Bank, Washington D.C.

Alam A, Murthi M, Yemtsov R, Murrugarra E, Dudwick N, Hamilton E, Tiongson E (2005) Growth Poverty and Inequality. Eastern Europe and the Former Soviet Union. The World Bank, Washington DC

Barham B, Boucher S (1998) Migration remittances and inequality: estimating the net effect of migration on income distribution. J Dev Econ 55(2):307-331

Caliendo M, Kopeinig S (2008) Some practical guidance for the implementation of propensity score matching. J Econ Surv 22(1):31-72

Corbanese V, Rosas G (2007) Young People's Transition to Decent Work: Evidence from Kosovo. Employment Policy Papers 2007 (4). International Labour Office, Geneva

Coudouel A, Hentschel JS, Wodon QT (2000) Poverty measurement and analysis. In: Poverty Reduction Strategy Sourcebook. World Bank, Washington, DC

Davis B, Carletto G, Winters P (2010) Migration, transfers and economic decision making among agricultural households: an introduction. J Dev Stud 46(1):1-13

De Haan A, Rogaly B (2002) Introduction: migrant workers and their role in rural change. J Dev Stud 38(5):1-14

Elezaj E, Bislimi F, Duri I (2012) Kosovo Remittance Study 2012. United Nations Development Program (UNDP) - Kosovo, Prishtina, KS

Ellis F (2000) Rural Livelihoods and Diversity in Developing Countries. Oxford University Press, Oxford

European Stability Initiative [ESI] (2006) Cutting the lifeline: Migration, families and the future of Kosovo. European Stability Initiative (ESI), Berlin, D, and Istanbul, TR

Foster J, Greer J, Thorbecke E (1984) A class of decomposable poverty measures. Econometrica 52(3):761-765

Gashi A, Haxhikadrija A (2012) Social impact of Emigration and Rural-urban Migration in Central and Eastern Europe. Final Country Report Kosovo. European Commission, ec.europa.eu/social/BlobServlet?docld=8861\&langld=en, accessed May 2014

Giannetti M, Federici D, Raitano M (2009) Migrant remittances and inequality in Central-Eastern Europe. Int Rev Appl Econ 23(3):289-307

Göbel K (2013) Remittances, expenditure patterns, and gender: parametric and semiparametric evidence from Ecuador. IZA J Migr 2(1):1-19

Havolli S (2011) Determinants of migrants' earnings and remittances: evidence from Kosovo. Focus on European Economic Integration Q1(11):90-99

Haxhikadrija A (2009) Diaspora as a driving force in the development of Kosovo: myth or reality? http://www.swisscooperation.admin.ch/kosovo/en/Home/Publications, 18.06.2014

Imbens G, Rubin DB (2014) An Introduction to Causal Inference in Statistics, Biomedical and Social Science. Cambridge University press, New York

Jimenez-Soto E, Brown R (2012) Assessing the poverty impacts of migrants' remittances using propensity score matching: the case of Tonga. Econ Rec 88(282):425-439

Lerman RI, Yitzhaki S (1994) Effect of marginal changes in income sources on US income inequality. Public Finan Q 22(4):403-417

Lokshin M, Bontch-Osmolovski M, Glinskaya E (2010) Work-related migration and poverty reduction in Nepal. Rev Dev Econ 14(2):323-332

Mansoor A, Quillin B (2006) Migration and Remittances. Eastern Europe and the Former Soviet Union. The World Bank, Washington DC

McKenzie D, Sasin MJ (2007) Migration, Remittances, Poverty, and Human Capital: Conceptual and Empirical Challenges, World Bank Policy Research Working Paper No. 4272. The World Bank, Washington D.C

Meyer W, Möllers J, Buchenrieder G (2012) Who remits more and who remits less? Evidence from Kosovar migrants living in Germany and the corresponding origin households. Oxf Dev Stud 40(4):443-466

Milanovic B (1987) Remittances and income distribution. J Econ Stud 14(5):24-37 
Miluka J, Carletto G, Davis B, Zezza A (2010) The vanishing farms? The impact of international migration on Albanian family farming. J Dev Stud 46(1):140-161

Möllers J, Meyer W, Xhema S, Buchenrieder G (2013) A socio-economic picture of Kosovar migrants and their origin farm households, IAMO Discussion Paper No. 140. Leibniz Institute of Agricultural Development in Transition Economies (IAMO), Halle (Saale), D

Mosse D, Gupta S, Mehta M, Shah V, Rees J (2002) Brokered livelihoods: debt, labour migration and development in tribal Western India. J Dev Stud 38(5):59-88

Mustafa M, Kotorri M, Gashi P, Gashi A, Demukaj V (2007) Diaspora and Migration Policies. Riinvest, Prishtina

Pastore F, Sattar S, Tiongson E (2013) Gender differences in earnings and labour supply in early career. Evidence from Kosovo's school-to-work transition survey. IZA J Labor Dev 2(5):1-34

Ravallion M (1998) Poverty Lines in Theory and Practice, Living Standards Measurement Study Working Paper No. 133. World Bank, Washington, DC

Reardon T, Taylor JE, Stamoulis K, Lanjouw P, Balisacan A (2000) Effects of nonfarm employment on rural income inequality in developing countries: an investment perspective. J Agric Econ 51(2):266-288

Shorrocks AF (1982) Inequality decomposition by factor components. Econometrica 50(1):193-212

Stark O, Taylor JE, Yitzhaki S (1988) Migration, remittances, and inequality: a sensitivity analysis using the extended Gini index. J Dev Econ 28(3):309-322

Statistical Office of Kosovo [SOK] (2010) Household Budget Survey 2009. Series 5: Social Statistics. http://ask.rks-gov.net/ ENG/hbs/tables, 18.06.2014

Taylor JE (1992) Remittances and inequality reconsidered: direct, indirect and intertemporal effects. J Policy Model 14 (2): $187-208$

Taylor JE, Wyatt TJ (1996) The shadow value of migrant remittances, income and inequality in a household-farm economy. J Dev Stud 32(6):899-912

United Nations Development Programme (2010) Kosovo Remittance Study 2010. UNDP, Prishtina

United Nations Development Programme (2011) Kosovo Remittance Survey 2011, Fast Facts. UNDP, Prishtina

United States Agency for International Development [USAID] (2008) Kosovo Economic Performance Assessment. http://pdf.usaid.gov/pdf_docs/PNADL767.pdf, 2.5.2014

Vathi Z, Black R (2007) Migration and poverty reduction in Kosovo, Development Research Centre (DRC) of Migration Globalisation and Poverty DRC on Migration, Globalisation and Poverty Working Paper No. C 12. Development Research Centre on Migration, Globalisation and Poverty, Brighton

Verme P (2011) The poverty reduction capacity of public and private transfers in transition. J Dev Stud 47(6):870-893

World Bank (2000) Making Transition Work for Everyone: Poverty and Inequality in Europe and Central Asia. The World Bank, Washington, D.C.

World Bank (2007a) Kosovo poverty assessment. Report No. 39737-XK. The World Bank, Washington D.C.

World Bank (2007b) World Development Report 2008: Agriculture for Development. The World Bank, Washington D.C.

World Bank (2010) World Bank indicators: workers' remittances and compensation of employees, received (current US\$), retrieved November 4, 2010. http://data.worldbank.org/indicator/BX.TRF.PWKR.CD.DT

World Bank and SOK (2011) Consumption Poverty in the Republic of Kosovo in 2009. The World Bank, Washington D.C.

10.1186/2193-9020-3-16

Cite this article as: Möllers and Meyer: The effects of migration on poverty and inequality in rural Kosovo. IZA Journal of Labor \& Development 2014, 3:16

\section{Submit your manuscript to a SpringerOpen ${ }^{\circ}$ journal and benefit from:}

- Convenient online submission

- Rigorous peer review

- Immediate publication on acceptance

- Open access: articles freely available online

- High visibility within the field

- Retaining the copyright to your article

Submit your next manuscript at $\boldsymbol{\nabla}$ springeropen.com 